\title{
Role of Muscarinic Acetylcholine Signaling in Gastrointestinal Cancers
}

\author{
Mitsuru Konishi@, Yoku Hayakawa *(1) and Kazuhiko Koike \\ Department of Gastroenterology, Graduate School of Medicine, The University of Tokyo, Tokyo 1138655, Japan \\ * Correspondence: yhayakawa-tky@umin.ac.jp; Tel.: +81-3-3815-5411; Fax: +81-3-5800-8812
}

Received: 10 July 2019; Accepted: 7 August 2019; Published: 10 August 2019

\begin{abstract}
In the tumor microenvironment, various stromal and immune cells accumulate and interact with cancer cells to contribute to tumor progression. Among stromal players, nerves have recently been recognized as key regulators of tumor growth. More neurotransmitters, such as catecholamines and acetylcholine (ACh), are present in tumors, as the cells that secrete neurotransmitters accumulate by the release of neurotrophic factors from cancer cells. In this short review, we focus on the role of nerve signaling in gastrointestinal (GI) cancers. Given that muscarinic acetylcholine receptor signaling seems to be a dominant regulator of GI stem cells and cancers, we review the function and mechanism of the muscarinic ACh pathway as a regulator of GI cancer progression. Accumulating evidence suggests that ACh, which is secreted from nerves and tuft cells, stimulates GI epithelial stem cells and contributes to cancer progression via muscarinic receptors.
\end{abstract}

Keywords: muscarinic acetylcholine receptor; tuft cell; gastric cancer; colon cancer

\section{Interaction between Nerves and Cancers}

There has been accumulating evidence on the neural regulation of tissue stem cells and the promoting role of nerves and neurotransmitters in cancer initiation and progression [1-9]. For instance, Brownell et al. reported that a nerve-dependent microenvironment creates a molecularly and phenotypically distinct population of hair follicle stem cells via the Sonic hedgehog (SHH) pathway [1]. Hanoun et al. reported that the sympathetic nervous system promotes the infiltration of leukemic cells into bone marrow in an MLL-AF9 AML model [2]. Katayama et al. reported that hematopoietic stem and progenitor cells in the bone marrow are regulated by the sympathetic nervous system, which attracts hematopoietic stem cells to their niche [3]. Magnon et al. reported that the autonomic nerve fibers, both adrenergic and cholinergic, in the prostate gland regulate prostate cancer development and dissemination in mouse models [4]. The authors later revealed that during this process, adrenergic signals regulate angiogenesis in prostate cancer tissues via metabolic changes in endothelial cells $[10,11]$. Mendez-Ferrer et al. reported that Nestin-expressing mesenchymal stem cells (MSCs) constitute an essential hematopoietic stem cell niche via adrenergic receptor signaling [5]. Peterson et al. reported that Gli1-expressing progenitors within mechanosensory touch dome epithelia are activated by sensory nerves via Hedgehog signaling in normal touch domes and contribute to tumorigenesis, while denervation attenuates these tumors [6]. Stopczynski et al. reported that neurotrophic factors and sensory nerves are increased during pancreatic cancer development, and metastatic tumor cells could be found along with the celiac and sensory ganglia in the spinal cord [7]. Furthermore, Renz et al. demonstrated that adrenergic signals promote pancreatic cancer progression, while cholinergic signals inhibit pancreatic cancer progression $[12,13]$. Venkatesh et al. reported that the synaptic protein neuroligin-3 (NLGN3) activates the PI3K-mTOR pathway and induces the feedforward expression of NLGN3 in glioma cells, and NLGN3 promotes robust high-grade glioma cell proliferation [8]. Zhao et al. reported that the vagus nerve contributes to gastric tumorigenesis via 
muscarinic acetylcholine receptor 3-mediated Wnt signaling in the gastric stem cells [9]. Thus, nerves and neuronal signals widely regulate cancer progression within the tumor microenvironment.

Neurite outgrowth from nerves is caused by the neurotrophic factors secreted from cancer cells. On the other hand, nerves, which can be adrenergic, cholinergic, or of sensory origin, release various neurotransmitters from their endings and stimulate stromal cells, immune cells, and cancer cells, resulting in the promotion of cancer initiation, progression, and metastasis [14]. Therefore, there is a bidirectional interaction between nerves, cancer cells, and other stromal cells, and nerve signaling plays a central role in the complex tumor microenvironment.

\section{Muscarinic Acetylcholine (ACh) Receptors}

Muscarinic ACh receptors are members of the G protein-coupled receptors (GPCRs) that activate $5^{\prime}$-phosphate $(\mathrm{G})$ proteins. GPCRs regulate a variety of biological processes by modulating the activation of adenylyl cyclase, the turnover of phosphatidylinositol lipid, and the status of ion channels [15-17]. Like other GPCRs, muscarinic ACh receptors have seven transmembrane helical domains that are connected by three extracellular and three intracellular loops. To date, five muscarinic ACh receptor subtypes have been identified and termed as CHRM1-5. These receptors regulate various cellular functions through different signaling pathways [17-19]. In general, CHRM1, CHRM3, and CHRM5 activate the phospholipid turnover and change the cellular calcium concentration. CHRM2 and CHRM4 inhibit the activity of adenylyl cyclase and reduce levels of cyclic adenosine monophosphate (cAMP). Muscarinic ACh receptors are widely expressed throughout the body, including in the gut, brain, eye, heart, vasculature, etc. [20-28]. In particular, CHRM1 and CHRM3 are robustly expressed in the gastrointestinal (GI) tract. In the stomach, ACh is secreted from vagus nerve endings, and gastric acid secretion from parietal cells is caused by CHRM3 [29-32], while pepsinogen secretion from gastric chief cells is promoted by CHRM1 and CHRM3 [33-36]. In addition, a low expression of CHRM5 has been reported in the gastric epithelium [9,37]. CHRM1 and CHRM3 appear to be expressed in normal colonic epithelia as well $[17,38]$. The influence of muscarinic receptors is highly diversified, depending on the cellular environment and proteome [39].

\section{ACh Signaling and Gastric Cancer}

In a recent study involving three mouse models of gastric cancer (genetically engineered, chemically induced, and Helicobacter pylori-induced), surgical vagotomy significantly attenuated gastric tumorigenesis. In addition, pharmacological denervation using botulinum toxin A or a blockade of muscarinic acetylcholine receptor 3 (M3R) inhibited tumorigenesis [9,40]. Interestingly, Lgr5+ gastric antral stem cells highly express Chrm3, the gene encoding M3R, suggesting that Lgr5+ stem cell function is modulated by M3R signaling [9]. Indeed, denervation inhibits Wnt signaling in gastric stem cells and suppresses stem cell expansion during carcinogenesis. In humans, tumor stage is correlated with nerve density in gastric cancer tissues, whereas vagotomy reduces the risk of gastric cancer recurrence [9].

Like other GPCRs, the activation of M3R leads to a variety of biochemical and electrophysiological responses, but the resulting physiological effects depend on the cell type and/or tissue type. M3R has been suggested to activate mitogen-activated protein kinase (MAPK) [41-44], Akt [25,43,45], or ras homolog family member A (RhoA) [46,47], thereby contributing to tumor growth in various cancers [48] (Figure 1). Subsequent studies have shown that M3R signaling promotes cellular proliferation and inhibits apoptosis via the epidermal growth factor receptor (EGFR) and Akt pathways in human gastric cancer cell lines and xenografts $[49,50]$. 


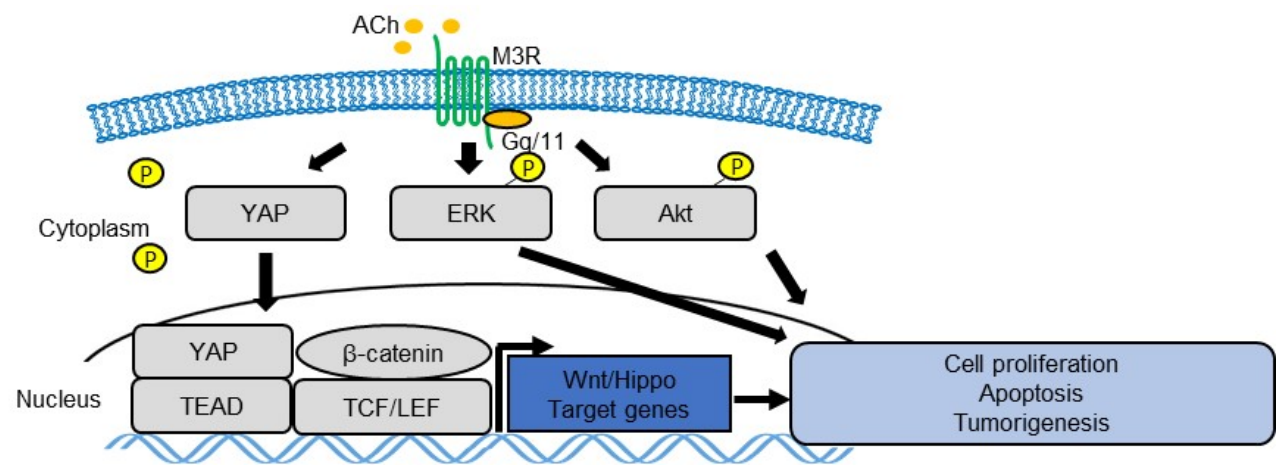

Figure 1. Schema of ACh-muscarinic acetylcholine receptor 3 (M3R) signaling pathway in gastrointestinal (GI) tumor cells. ACh-M3R signaling regulates cell proliferation, survival, and tumorigenesis by activating various signaling pathways, such as mitogen-activated protein kinase (MAPK), Akt, yes-associated protein (YAP), and Wnt.

The yes-associated protein (YAP), a downstream effector of the Hippo pathway, regulates various cellular functions, such as proliferation, survival, stemness, and pluripotency [51,52]. In the Apc-dependent gastrointestinal tumors, YAP is highly upregulated and activated, and YAP activation appears to be required for the growth of Apc/ $\beta$-catenin-dependent tumors [53-55]. Indeed, YAP regulates tissue regeneration and tumorigenesis in multiple organs, including the stomach and intestines, by activating tissue stem cells [56-58]. It was also suggested that types of GPCRs that activate G12/13, Gq/11, or Gi/o can activate YAP by suppressing its phosphorylation, whereas types of GPCRs that mainly activate Gs signaling can phosphorylate and, therefore, inhibit the YAP pathway [59]. Zhou et al. reported that SRY-Box9 (SOX9), which is known to be upregulated in gastric tissues during carcinogenesis [60], regulates the expression and phosphorylation of YAP in gastric cancer cell lines [61]. They also reported that SOX9 enhanced the proliferation, invasion, and migration of gastric cancer cells, and SOX9 may enhance the epithelial-mesenchymal transition (EMT) in gastric cancer cells via the Hippo-YAP pathway [61], supporting the notion that the Hippo-YAP pathway plays a critical role in gastric cancer progression. Similarly, our group demonstrated that M3R activates YAP signaling in gastric cancer cells, similar to the actions of other $\mathrm{Gq} / 11$ family receptors, and regulates the subsequent activation of Wnt in gastric tumors [48]. Thus, M3R and YAP could be a potential therapeutic target of nerve-dependent cancer development [51,62] (Figure 1).

\section{Tuft Cells as a Source of ACh}

Results of studies involving vagotomy have suggested that the vagus nerve is the main source of ACh secretion in the GI tract, but also that an alternative source of ACh exists in the GI epithelium. It has been reported that differentiated tuft cells, which commonly express doublecortin like kinase 1 (Dclk1), also express choline acetyltransferase (ChAT) and act as an epithelial source of ACh $[48,63]$. During carcinogenesis, tuft cells expand earlier and nerves expand later within cancerous tissues, resulting in the increase in ACh concentration in tissues. In particular, tuft cells expand dramatically in inflammation-associated cancer models and contribute to early cancer growth and the remodeling of the peritumoral neural microenvironment [48]. Furthermore, mouse models suggest that cholinergic stimulation of the gastric epithelium, in part, through ACh secretion from tuft cells, induces nerve growth factor (NGF) expression. NGF overexpression in the gastric epithelium, in turn, expands axonal growth from nerves in the lamina propria, and eventually promotes carcinogenesis by activating gastric stem cells [48]. Indeed, the ablation of Dclk1+ tuft cells and blockade of NGF/Trk signaling inhibit epithelial regeneration and tumorigenesis in an M3R-dependent manner, highlighting the importance of tuft cells as a component of the cancer niche. This feedforward ACh-NGF axis offers a compelling target for tumor treatment and prevention [48] (Figure 2). 


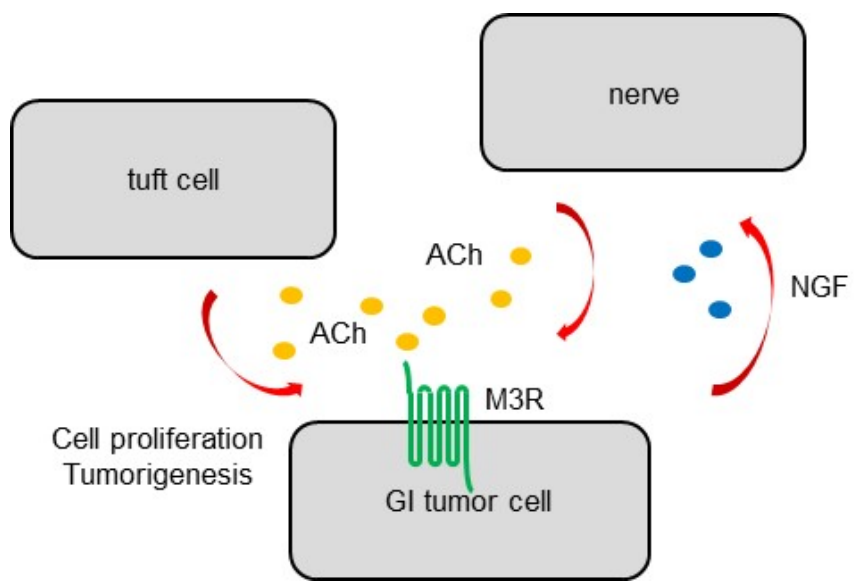

Figure 2. Schema of GI cancer cells and ACh sources. The nerve is the main source of ACh secretion. Dclk1+ tuft cells act as an alternative epithelial source of ACh. Nerves and tuft cells in the stomach and intestines expand at discrete times during carcinogenesis, leading to an increased ACh concentration in cancerous tissues. Cholinergic stimulation of the gastric epithelium induces nerve growth factor (NGF) expression, and, in turn, NGF overexpression in the gastric epithelium expands enteric nerves and promotes carcinogenesis.

\section{ACh Signaling and Colon Cancer}

Evidence suggests that ACh-M3R signaling also plays a role in colonic carcinogenesis [64]. In ApcMin mice carrying the Apc gene mutation, the simultaneous knockout of the Chrm3 gene leads to the reduction in intestinal tumor load. $\beta$-catenin nuclear staining is attenuated in ApcMin/+Chrm3-/- mice compared to in ApcMin/+Chrm3+/+ mice with tumors, suggesting a similar regulatory mechanism of Wnt activation by M3R signaling [65]. Another study demonstrated that M3R-deficient mice have an attenuated cell proliferation, tumor number, and tumor size in chemically induced colon tumor models [38]. In addition, treatment with bethanechol, a muscarinic agonist, increases colonic proliferation by upregulating selected matrix metalloproteinase (Mmp) genes and Wnt target genes such as Myc and cyclin D1 [66]. Collectively, these findings support important roles for M3R expression and activation in the progression of colon neoplasia [67]. M3R and its downstream signaling pathway may be a promising therapeutic target of colon cancer [68].

While the relationship between M3R and YAP signaling has been suggested in gastric cancers [48], it remains undetermined whether such a clear connection between these two pathways also exists in intestinal cancers. Several studies have suggested that YAP signaling generally promotes epithelial regeneration and tumor development in intestines, primarily by stimulating tissue stem cells and progenitors $[56,69,70]$. The YAP pathway also plays a role in the regulation of colonic cell death/apoptosis, invasion, or metastasis [71,72]. Nevertheless, given that the opposite effects by YAP signaling on intestinal tumor development have been reported [62,73], further studies would be required to understand the precise function of this pathway in nerve-dependent tumorigenesis.

During inflammation-associated colon cancer development, vagus nerves also mediate anti-inflammatory reflux in the spleen [74]. Vagus stimuli promote the secretion of trefoil factor 2 (TFF2), an anti-inflammatory peptide, from memory $\mathrm{T}$ cells, which leads to the suppression of myeloid cells and the alteration of the inflammatory microenvironment in colonic tumors. Myeloid cells are also known as a source of Wnt ligands in the intestines and contribute to epithelial regeneration [75]. Therefore, vagus nerve signaling and ACh signaling are involved in colonic carcinogenesis in a complicated manner.

As demonstrated in the stomach, Dclk1+ tuft cells contribute to colonic regeneration and homeostasis, at least, in part, through ACh/M3R signaling. The ablation of Dclk1+ tuft cells in the colon leads to a significant reduction in epithelial proliferation, and exaggerated epithelial damage, after dextran sodium sulfate (DSS)-induced colitis [76]. In contrast, the overexpression of NGF and 
subsequent increased nerve signaling promoted epithelial repair following colonic injury, whereas M3R knockout in the colonic epithelium worsened the outcome, in a DSS-induced colitis model [48]. Interestingly, the conditional knockdown of Apc in Dclk1+ tuft cells is insufficient to drive colonic carcinogenesis under normal conditions; however, DSS-induced colitis induces the development of poorly differentiated colonic adenocarcinoma in mice specifically lacking the Apc gene in Dclk1+ tuft cells [76], suggesting that Dclk1+ tuft cells also act as cancer-initiating cells under specific conditions. In addition, in vitro co-culture experiments showed that nerves fail to support organoid growth in the absence of Dclk1+ tuft cells, suggesting that Dclk1+ cells are involved in the integration of neuronal signals in the epithelium [76]. More recently, Goto et al. identified interleukin 17 receptor B (IL17RB) as a cell-specific marker of tuft cells, and showed that IL17RB regulates tuft cell-derived cancer stem cell function and could be a therapeutic target [77].

\section{Conclusions}

M3R signaling regulates cell proliferation, survival, and tumorigenesis by activating various signaling pathways, such as MAPK, Akt, YAP, Wnt, and NGF, in GI cancers. In addition to nerves, tuft cells serve as sources of ACh in the GI tract and contribute to regeneration and homeostasis. Components and involved signaling pathways in nerve-tumor interactions may be a promising target for the treatment of cancers of the GI tract.

Funding: Y.H. is supported by the KAKENHI Grant-in-Aid for Scientific Research, 17K09347 and 17H05081, P-CREATE from AMED, the Pharmacological Research Foundation, the research grant of Bristol-Myers Squibb, the Kowa Life Science Foundation, the Senshin Medical Research Foundation, the Yokoyama Clinical Pharmacological Research Foundation, the Kanae Foundation of the Promotion of Medical Science, the Inoue Science Research Award, the Takeda Science Foundation Visionary Research Grant, the Princess Takamatsu Cancer Research Fund, and the Advanced Research and Development Programs for Medical Innovation (PRIME). M.K. is supported by a research grant from the Institute for Adult Diseases, Asahi Life Foundation.

Conflicts of Interest: The authors declare no conflict of interest. The funders had no role in the design of the study; in the collection, analyses, or interpretation of data; in the writing of the manuscript, or in the decision to publish the results.

\section{References}

1. Brownell, I.; Guevara, E.; Bai, C.B.; Loomis, C.A.; Joyner, A.L. Nerve-derived sonic hedgehog defines a niche for hair follicle stem cells capable of becoming epidermal stem cells. Cell Stem Cell 2011, 8, 552-565. [CrossRef] [PubMed]

2. Hanoun, M.; Zhang, D.; Mizoguchi, T.; Pinho, S.; Pierce, H.; Kunisaki, Y.; Lacombe, J.; Armstrong, S.A.; Duhrsen, U.; Frenette, P.S. Acute myelogenous leukemia-induced sympathetic neuropathy promotes malignancy in an altered hematopoietic stem cell niche. Cell Stem Cell 2014, 15, 365-375. [CrossRef] [PubMed]

3. Katayama, Y.; Battista, M.; Kao, W.M.; Hidalgo, A.; Peired, A.J.; Thomas, S.A.; Frenette, P.S. Signals from the sympathetic nervous system regulate hematopoietic stem cell egress from bone marrow. Cell 2006, 124, 407-421. [CrossRef] [PubMed]

4. Magnon, C.; Hall, S.J.; Lin, J.; Xue, X.; Gerber, L.; Freedland, S.J.; Frenette, P.S. Autonomic nerve development contributes to prostate cancer progression. Science 2013, 341, 1236361. [CrossRef] [PubMed]

5. Mendez-Ferrer, S.; Michurina, T.V.; Ferraro, F.; Mazloom, A.R.; Macarthur, B.D.; Lira, S.A.; Scadden, D.T.; Ma'ayan, A.; Enikolopov, G.N.; Frenette, P.S. Mesenchymal and haematopoietic stem cells form a unique bone marrow niche. Nature 2010, 466, 829-834. [CrossRef] [PubMed]

6. Peterson, S.C.; Eberl, M.; Vagnozzi, A.N.; Belkadi, A.; Veniaminova, N.A.; Verhaegen, M.E.; Bichakjian, C.K.; Ward, N.L.; Dlugosz, A.A.; Wong, S.Y. Basal cell carcinoma preferentially arises from stem cells within hair follicle and mechanosensory niches. Cell Stem Cell 2015, 16, 400-412. [CrossRef]

7. Stopczynski, R.E.; Normolle, D.P.; Hartman, D.J.; Ying, H.; DeBerry, J.J.; Bielefeldt, K.; Rhim, A.D.; DePinho, R.A.; Albers, K.M.; Davis, B.M. Neuroplastic changes occur early in the development of pancreatic ductal adenocarcinoma. Cancer Res. 2014, 74, 1718-1727. [CrossRef] 
8. Venkatesh, H.S.; Johung, T.B.; Caretti, V.; Noll, A.; Tang, Y.; Nagaraja, S.; Gibson, E.M.; Mount, C.W.; Polepalli, J.; Mitra, S.S.; et al. Neuronal Activity Promotes Glioma Growth through Neuroligin-3 Secretion. Cell 2015, 161, 803-816. [CrossRef]

9. Zhao, C.M.; Hayakawa, Y.; Kodama, Y.; Muthupalani, S.; Westphalen, C.B.; Andersen, G.T.; Flatberg, A.; Johannessen, H.; Friedman, R.A.; Renz, B.W.; et al. Denervation suppresses gastric tumorigenesis. Sci. Transl. Med. 2014, 6, 250ra115. [CrossRef]

10. Zahalka, A.H.; Arnal-Estape, A.; Maryanovich, M.; Nakahara, F.; Cruz, C.D.; Finley, L.W.S.; Frenette, P.S. Adrenergic nerves activate an angio-metabolic switch in prostate cancer. Science 2017, 358, 321-326. [CrossRef]

11. Hayakawa, Y.; Wang, T.C. Nerves switch on angiogenic metabolism. Science 2017, 358, 305-306. [CrossRef] [PubMed]

12. Renz, B.W.; Takahashi, R.; Tanaka, T.; Macchini, M.; Hayakawa, Y.; Dantes, Z.; Maurer, H.C.; Chen, X.; Jiang, Z.; Westphalen, C.B.; et al. $\beta 2$ Adrenergic-Neurotrophin Feedforward Loop Promotes Pancreatic Cancer. Cancer Cell 2018, 33, 75-90. [CrossRef] [PubMed]

13. Renz, B.W.; Tanaka, T.; Sunagawa, M.; Takahashi, R.; Jiang, Z.; Macchini, M.; Dantes, Z.; Valenti, G.; White, R.A.; Middelhoff, M.A.; et al. Cholinergic Signaling via Muscarinic Receptors Directly and Indirectly Suppresses Pancreatic Tumorigenesis and Cancer Stemness. Cancer Discov. 2018, 8, 1458-1473. [CrossRef] [PubMed]

14. Faulkner, S.; Jobling, P.; March, B.; Jiang, C.C.; Hondermarck, H. Tumor Neurobiology and the War of Nerves in Cancer. Cancer Discov. 2019, 9, 702-710. [CrossRef] [PubMed]

15. Gilman, A.G. G proteins and dual control of adenylate cyclase. Cell 1984, 36, 577-579. [CrossRef]

16. Malbon, C.C. G proteins in development. Nat. Rev. Mol. Cell Biol. 2005, 6, 689-701. [CrossRef] [PubMed]

17. Von Rosenvinge, E.C.; Raufman, J.P. Muscarinic receptor signaling in colon cancer. Cancers 2011, 3, $971-981$. [CrossRef] [PubMed]

18. Bonner, T.I.; Buckley, N.J.; Young, A.C.; Brann, M.R. Identification of a family of muscarinic acetylcholine receptor genes. Science 1987, 237, 527-532. [CrossRef] [PubMed]

19. Kruse, A.C.; Li, J.; Hu, J.; Kobilka, B.K.; Wess, J. Novel insights into $\mathrm{M}_{3}$ muscarinic acetylcholine receptor physiology and structure. J. Mol. Neurosci. 2014, 53, 316-323. [CrossRef] [PubMed]

20. Abrams, P.; Andersson, K.E.; Buccafusco, J.J.; Chapple, C.; De Groat, W.C.; Fryer, A.D.; Kay, G.; Laties, A.; Nathanson, N.M.; Pasricha, P.J.; et al. Muscarinic receptors: Their distribution and function in body systems, and the implications for treating overactive bladder. Br. J. Pharm. 2006, 148, 565-578. [CrossRef]

21. Pronin, A.N.; Wang, Q.; Slepak, V.Z. Teaching an Old Drug New Tricks: Agonism, Antagonism, and Biased Signaling of Pilocarpine through $\mathrm{M}_{3}$ Muscarinic Acetylcholine Receptor. Mol. Pharm. 2017, 92, 601-612. [CrossRef] [PubMed]

22. Wang, Z.; Shi, H.; Wang, H. Functional $\mathrm{M}_{3}$ muscarinic acetylcholine receptors in mammalian hearts. Br. J. Pharm. 2004, 142, 395-408. [CrossRef] [PubMed]

23. Kovacevic, I.; Muller, M.; Kojonazarov, B.; Ehrke, A.; Randriamboavonjy, V.; Kohlstedt, K.; Hindemith, T.; Schermuly, R.T.; Fleming, I.; Hoffmeister, M.; et al. The F-BAR Protein NOSTRIN Dictates the Localization of the Muscarinic $\mathrm{M}_{3}$ Receptor and Regulates Cardiovascular Function. Circ. Res. 2015, 117, 460-469. [CrossRef] [PubMed]

24. Radu, B.M.; Osculati, A.M.M.; Suku, E.; Banciu, A.; Tsenov, G.; Merigo, F.; Di Chio, M.; Banciu, D.D.; Tognoli, C.; Kacer, P.; et al. All muscarinic acetylcholine receptors $\left(\mathrm{M}_{1}-\mathrm{M}_{5}\right)$ are expressed in murine brain microvascular endothelium. Sci. Rep. 2017, 7, 5083. [CrossRef] [PubMed]

25. He, Y.; Lin, G.; Han, D.; Shi, D.; Liu, T.; Gao, Y.; Guan, W.; Cheng, G. Aclidinium Bromide holds promising inhibitory effects in A549 lung cancer cells potentials by regulating PI3K/AKT signaling pathway. J. Buon. 2019, 24, 560-565.

26. Fryer, A.D.; Jacoby, D.B. Muscarinic receptors and control of airway smooth muscle. Am. J. Respir. Crit. Care Med. 1998, 158, S154-S160. [CrossRef] [PubMed]

27. Wei, W.; Wang, M.; Li, Y.; Meng, Q.; Tang, Y.; Lu, H.; Yu, W.; Cheng, Q.; Xu, L.; Jian, S.; et al. Muscarinic cholinergic signaling and overactive bladder-like symptoms associated with invasive bladder cancer. Oncol. Lett. 2018, 16, 775-784. [CrossRef]

28. Kitazawa, T.; Hirama, R.; Masunaga, K.; Nakamura, T.; Asakawa, K.; Cao, J.; Teraoka, H.; Unno, T.; Komori, S.; Yamada, M.; et al. Muscarinic receptor subtypes involved in carbachol-induced contraction of mouse uterine smooth muscle. Naunyn. Schmiedebergs Arch. Pharm. 2008, 377, 503-513. [CrossRef] 
29. Ecknauer, R.; Dial, E.; Thompson, W.J.; Johnson, L.R.; Rosenfeld, G.C. Isolated rat gastric parietal cells: Cholinergic response and pharmacology. Life Sci. 1981, 28, 609-621. [CrossRef]

30. Soll, A.H. Specific inhibition by prostaglandins E2 and I2 of histamine-stimulated [14C] aminopyrine accumulation and cyclic adenosine monophosphate generation by isolated canine parietal cells. J. Clin. Investig. 1980, 65, 1222-1229. [CrossRef]

31. Aihara, T.; Fujishita, T.; Kanatani, K.; Furutani, K.; Nakamura, E.; Taketo, M.M.; Matsui, M.; Chen, D.; Okabe, S. Impaired gastric secretion and lack of trophic responses to hypergastrinemia in M3 muscarinic receptor knockout mice. Gastroenterology 2003, 125, 1774-1784. [CrossRef]

32. Kajimura, M.; Reuben, M.A.; Sachs, G. The muscarinic receptor gene expressed in rabbit parietal cells is the $\mathrm{m}_{3}$ subtype. Gastroenterology 1992, 103, 870-875. [CrossRef]

33. Raufman, J.P.; Sutliff, V.E.; Kasbekar, D.K.; Jensen, R.T.; Gardner, J.D. Pepsinogen secretion from dispersed chief cells from guinea pig stomach. Am. J. Physiol. 1984, 247, G95-G104. [CrossRef]

34. Sutliff, V.E.; Rattan, S.; Gardner, J.D.; Jensen, R.T. Characterization of cholinergic receptors mediating pepsinogen secretion from chief cells. Am. J. Physiol. 1989, 257, G226-G234. [CrossRef]

35. Xie, G.; Drachenberg, C.; Yamada, M.; Wess, J.; Raufman, J.P. Cholinergic agonist-induced pepsinogen secretion from murine gastric chief cells is mediated by $\mathrm{M}_{1}$ and $\mathrm{M}_{3}$ muscarinic receptors. Am. J. Physiol. Gastrointest. Liver Physiol. 2005, 289, G521-G529. [CrossRef]

36. Tobin, G.; Giglio, D.; Lundgren, O. Muscarinic receptor subtypes in the alimentary tract. J. Physiol. Pharm. 2009, 60, 3-21.

37. Aihara, T.; Nakamura, Y.; Taketo, M.M.; Matsui, M.; Okabe, S. Cholinergically stimulated gastric acid secretion is mediated by $\mathrm{M}_{3}$ and $\mathrm{M}_{5}$ but not $\mathrm{M}_{1}$ muscarinic acetylcholine receptors in mice. Am. J. Physiol. Gastrointest. Liver Physiol. 2005, 288, G1199-G1207. [CrossRef]

38. Raufman, J.P.; Samimi, R.; Shah, N.; Khurana, S.; Shant, J.; Drachenberg, C.; Xie, G.; Wess, J.; Cheng, K. Genetic ablation of M3 muscarinic receptors attenuates murine colon epithelial cell proliferation and neoplasia. Cancer Res. 2008, 68, 3573-3578. [CrossRef]

39. Ockenga, W.; Kuhne, S.; Bocksberger, S.; Banning, A.; Tikkanen, R. Non-neuronal functions of the $\mathrm{m}_{2}$ muscarinic acetylcholine receptor. Genes 2013, 4, 171-197. [CrossRef]

40. Rabben, H.L.; Zhao, C.M.; Hayakawa, Y.; Wang, T.C.; Chen, D. Vagotomy and Gastric Tumorigenesis. Curr. Neuropharmacol. 2016, 14, 967-972. [CrossRef]

41. Kodaira, M.; Kajimura, M.; Takeuchi, K.; Lin, S.; Hanai, H.; Kaneko, E. Functional muscarinic $m_{3}$ receptor expressed in gastric cancer cells stimulates tyrosine phosphorylation and MAP kinase. J. Gastroenterol. 1999, 34, 163-171. [CrossRef]

42. Said, A.H.; Hu, S.; Abutaleb, A.; Watkins, T.; Cheng, K.; Chahdi, A.; Kuppusamy, P.; Saxena, N.; Xie, G.; Raufman, J.P. Interacting post-muscarinic receptor signaling pathways potentiate matrix metalloproteinase-1 expression and invasion of human colon cancer cells. Biochem. J. 2017, 474, 647-665. [CrossRef]

43. Sales, M.E.; Espanol, A.J.; Salem, A.R.; Martinez, P.P.; Sanchez, Y.; Sanchez, F. Role of muscarinic acetylcholine receptors in Breast Cancer. Design of metronomic chemotherapy. Curr. Clin. Pharm. 2018. [CrossRef]

44. Felton, J.; Hu, S.; Raufman, J.P. Targeting M3 Muscarinic Receptors for Colon Cancer Therapy. Curr. Mol. Pharm. 2018, 11, 184-190. [CrossRef]

45. Song, P.; Sekhon, H.S.; Lu, A.; Arredondo, J.; Sauer, D.; Gravett, C.; Mark, G.P.; Grando, S.A.; Spindel, E.R. M3 muscarinic receptor antagonists inhibit small cell lung carcinoma growth and mitogen-activated protein kinase phosphorylation induced by acetylcholine secretion. Cancer Res. 2007, 67, 3936-3944. [CrossRef]

46. Belo, A.; Cheng, K.; Chahdi, A.; Shant, J.; Xie, G.; Khurana, S.; Raufman, J.P. Muscarinic receptor agonists stimulate human colon cancer cell migration and invasion. Am. J. Physiol. Gastrointest. Liver Physiol. 2011, 300, G749-G760. [CrossRef]

47. Kuol, N.; Stojanovska, L.; Apostolopoulos, V.; Nurgali, K. Role of the nervous system in cancer metastasis. J. Exp. Clin. Cancer Res. 2018, 37, 5. [CrossRef]

48. Hayakawa, Y.; Sakitani, K.; Konishi, M.; Asfaha, S.; Niikura, R.; Tomita, H.; Renz, B.W.; Tailor, Y.; Macchini, M.; Middelhoff, M.; et al. Nerve Growth Factor Promotes Gastric Tumorigenesis through Aberrant Cholinergic Signaling. Cancer Cell 2017, 31, 21-34. [CrossRef]

49. Wang, L.; Zhi, X.; Zhang, Q.; Wei, S.; Li, Z.; Zhou, J.; Jiang, J.; Zhu, Y.; Yang, L.; Xu, H.; et al. Muscarinic receptor $\mathrm{M}_{3}$ mediates cell proliferation induced by acetylcholine and contributes to apoptosis in gastric cancer. Tumour. Biol. 2016, 37, 2105-2117. [CrossRef] 
50. Yu, H.; Xia, H.; Tang, Q.; Xu, H.; Wei, G.; Chen, Y.; Dai, X.; Gong, Q.; Bi, F. Acetylcholine acts through $\mathrm{M}_{3}$ muscarinic receptor to activate the EGFR signaling and promotes gastric cancer cell proliferation. Sci. Rep. 2017, 7, 40802. [CrossRef]

51. Calses, P.C.; Crawford, J.J.; Lill, J.R.; Dey, A. Hippo Pathway in Cancer: Aberrant Regulation and Therapeutic Opportunities. Trends Cancer 2019, 5, 297-307. [CrossRef]

52. Chen, Y.A.; Lu, C.Y.; Cheng, T.Y.; Pan, S.H.; Chen, H.F.; Chang, N.S. WW Domain-Containing Proteins YAP and TAZ in the Hippo Pathway as Key Regulators in Stemness Maintenance, Tissue Homeostasis, and Tumorigenesis. Front Oncol. 2019, 9, 60. [CrossRef]

53. Azzolin, L.; Panciera, T.; Soligo, S.; Enzo, E.; Bicciato, S.; Dupont, S.; Bresolin, S.; Frasson, C.; Basso, G.; Guzzardo, V.; et al. YAP/TAZ incorporation in the $\beta$-catenin destruction complex orchestrates the Wnt response. Cell 2014, 158, 157-170. [CrossRef]

54. Cai, J.; Maitra, A.; Anders, R.A.; Taketo, M.M.; Pan, D. $\beta$-Catenin destruction complex-independent regulation of Hippo-YAP signaling by APC in intestinal tumorigenesis. Genes Dev. 2015, 29, 1493-1506. [CrossRef]

55. Rosenbluh, J.; Nijhawan, D.; Cox, A.G.; Li, X.; Neal, J.T.; Schafer, E.J.; Zack, T.I.; Wang, X.; Tsherniak, A.; Schinzel, A.C.; et al. $\beta$-Catenin-driven cancers require a YAP1 transcriptional complex for survival and tumorigenesis. Cell 2012, 151, 1457-1473. [CrossRef]

56. Gregorieff, A.; Liu, Y.; Inanlou, M.R.; Khomchuk, Y.; Wrana, J.L. Yap-dependent reprogramming of Lgr5 ${ }^{+}$ stem cells drives intestinal regeneration and cancer. Nature 2015, 526, 715-718. [CrossRef]

57. Imajo, M.; Ebisuya, M.; Nishida, E. Dual role of YAP and TAZ in renewal of the intestinal epithelium. Nat. Cell Biol. 2015, 17, 7-19. [CrossRef]

58. Jiao, S.; Wang, H.; Shi, Z.; Dong, A.; Zhang, W.; Song, X.; He, F.; Wang, Y.; Zhang, Z.; Wang, W.; et al. A peptide mimicking VGLL4 function acts as a YAP antagonist therapy against gastric cancer. Cancer Cell 2014, 25, 166-180. [CrossRef]

59. Yu, F.X.; Zhao, B.; Panupinthu, N.; Jewell, J.L.; Lian, I.; Wang, L.H.; Zhao, J.; Yuan, H.; Tumaneng, K.; Li, H.; et al. Regulation of the Hippo-YAP pathway by G-protein-coupled receptor signaling. Cell 2012, 150, 780-791. [CrossRef]

60. Serizawa, T.; Hirata, Y.; Hayakawa, Y.; Suzuki, N.; Sakitani, K.; Hikiba, Y.; Ihara, S.; Kinoshita, H.; Nakagawa, H.; Tateishi, K.; et al. Gastric Metaplasia Induced by Helicobacter pylori is Associated with Enhanced SOX9 Expression via Interleukin-1 Signaling. Infect. Immun. 2015, 84, 562-572. [CrossRef]

61. Zhou, H.; Li, G.; Huang, S.; Feng, Y.; Zhou, A. SOX9 promotes epithelial-mesenchymal transition via the Hippo-YAP signaling pathway in gastric carcinoma cells. Oncol. Lett. 2019, 18, 599-608. [CrossRef]

62. Barry, E.R.; Morikawa, T.; Butler, B.L.; Shrestha, K.; Rosa, R.D.L.; Yan, K.S.; Fuchs, C.S.; Magness, S.T.; Smits, R.; Ogino, S.; et al. Restriction of intestinal stem cell expansion and the regenerative response by YAP. Nature 2013, 493, 106-110. [CrossRef]

63. Schutz, B.; Jurastow, I.; Bader, S.; Ringer, C.; Von Engelhardt, J.; Chubanov, V.; Gudermann, T.; Diener, M.; Kummer, W.; Krasteva-Christ, G.; et al. Chemical coding and chemosensory properties of cholinergic brush cells in the mouse gastrointestinal and biliary tract. Front Physiol. 2015, 6, 87. [CrossRef]

64. Cheng, K.; Xie, G.; Khurana, S.; Heath, J.; Drachenberg, C.B.; Timmons, J.; Shah, N.; Raufman, J.P. Divergent effects of muscarinic receptor subtype gene ablation on murine colon tumorigenesis reveals association of M3R and zinc finger protein 277 expression in colon neoplasia. Mol. Cancer 2014, 13, 77. [CrossRef]

65. Raufman, J.P.; Shant, J.; Xie, G.; Cheng, K.; Gao, X.M.; Shiu, B.; Shah, N.; Drachenberg, C.B.; Heath, J.; Wess, J.; et al. Muscarinic receptor subtype-3 gene ablation and scopolamine butylbromide treatment attenuate small intestinal neoplasia in Apc ${ }^{\text {min+ }}$ mice. Carcinogenesis 2011, 32, 1396-1402. [CrossRef]

66. Peng, Z.; Heath, J.; Drachenberg, C.; Raufman, J.P.; Xie, G. Cholinergic muscarinic receptor activation augments murine intestinal epithelial cell proliferation and tumorigenesis. BMC Cancer 2013, 13, 204. [CrossRef]

67. Cheng, K.; Shang, A.C.; Drachenberg, C.B.; Zhan, M.; Raufman, J.P. Differential expression of M3 muscarinic receptors in progressive colon neoplasia and metastasis. Oncotarget 2017, 8, 21106-21114. [CrossRef]

68. Tolaymat, M.; Larabee, S.M.; Hu, S.; Xie, G.; Raufman, J.P. The Role of M3 Muscarinic Receptor Ligand-Induced Kinase Signaling in Colon Cancer Progression. Cancers 2019, 11, 308. [CrossRef]

69. Hayakawa, Y.; Tsuboi, M.; Asfaha, S.; Kinoshita, H.; Niikura, R.; Konishi, M.; Hata, M.; Oya, Y.; Kim, W.; Middelhoff, M.; et al. BHLHA15-Positive Secretory Precursor Cells Can Give Rise to Tumors in Intestine and Colon in Mice. Gastroenterology 2019, 156, 1066-1081. [CrossRef] 
70. Yui, S.; Azzolin, L.; Maimets, M.; Pedersen, M.T.; Fordham, R.P.; Hansen, S.L.; Larsen, H.L.; Guiu, J.; Alves, M.R.P.; Rundsten, C.F.; et al. YAP/TAZ-Dependent Reprogramming of Colonic Epithelium Links ECM Remodeling to Tissue Regeneration. Cell Stem Cell 2018, 22, 35-49. [CrossRef]

71. Blanchard, T.G.; Lapidus, R.; Banerjee, V.; Bafford, A.C.; Czinn, S.J.; Ahmed, H.; Banerjee, A. Upregulation of RASSF1A in Colon Cancer by Suppression of Angiogenesis Signaling and Akt Activation. Cell. Physiol. Biochem. 2018, 48, 1259-1273. [CrossRef] [PubMed]

72. Wang, L.; Shi, S.; Guo, Z.; Zhang, X.; Han, S.; Yang, A.; Wen, W.; Zhu, Q. Overexpression of YAP and TAZ is an independent predictor of prognosis in colorectal cancer and related to the proliferation and metastasis of colon cancer cells. PLoS ONE 2013, 8, e65539. [CrossRef] [PubMed]

73. Ou, C.; Sun, Z.; Li, S.; Li, G.; Li, X.; Ma, J. Dual roles of yes-associated protein (YAP) in colorectal cancer. Oncotarget 2017, 8, 75727-75741. [CrossRef] [PubMed]

74. Dubeykovskaya, Z.; Si, Y.; Chen, X.; Worthley, D.L.; Renz, B.W.; Urbanska, A.M.; Hayakawa, Y.; Xu, T.; Westphalen, C.B.; Dubeykovskiy, A.; et al. Neural innervation stimulates splenic TFF2 to arrest myeloid cell expansion and cancer. Nat. Commun. 2016, 7, 10517. [CrossRef] [PubMed]

75. Saha, S.; Aranda, E.; Hayakawa, Y.; Bhanja, P.; Atay, S.; Brodin, N.P.; Li, J.; Asfaha, S.; Liu, L.; Tailor, Y.; et al. Macrophage-derived extracellular vesicle-packaged WNTs rescue intestinal stem cells and enhance survival after radiation injury. Nat. Commun. 2016, 7, 13096. [CrossRef] [PubMed]

76. Westphalen, C.B.; Asfaha, S.; Hayakawa, Y.; Takemoto, Y.; Lukin, D.J.; Nuber, A.H.; Brandtner, A.; Setlik, W.; Remotti, H.; Muley, A.; et al. Long-lived intestinal tuft cells serve as colon cancer-initiating cells. J. Clin. Investig. 2014, 124, 1283-1295. [CrossRef] [PubMed]

77. Goto, N.; Fukuda, A.; Yamaga, Y.; Yoshikawa, T.; Maruno, T.; Maekawa, H.; Inamoto, S.; Kawada, K.; Sakai, Y.; Miyoshi, H.; et al. Lineage tracing and targeting of IL17RB ${ }^{+}$tuft cell-like human colorectal cancer stem cells. Proc. Natl. Acad. Sci. USA 2019, 116, 12996-13005. [CrossRef]

(C) 2019 by the authors. Licensee MDPI, Basel, Switzerland. This article is an open access article distributed under the terms and conditions of the Creative Commons Attribution (CC BY) license (http://creativecommons.org/licenses/by/4.0/). 